\title{
Memorias colectivas, ideas de provincia y catolicismo en el debate parlamentario de la última ley de educación de Córdoba, Argentina (2010)*
}

\begin{abstract}
Resumen
El objetivo de este artículo es estudiar cómo las memorias colectivas sobre los pasados de las provincias se movilizan y generan ideas sobre las mismas que se plasman en políticas públicas educativas, sobre todo, en lo que refiere al vínculo entre educación de gestión estatal y religión. Para cumplir con esta meta, se seleccionó una estrategia de estudio de caso basada en el análisis del debate parlamentario de la última ley de educación de Córdoba. Se analizaron las versiones taquigráficas de este debate, rastreando fundamentalmente las referencias de los diputados al origen y el pasado de la jurisdicción, a la idea de provincia, y al encuadramiento de la relación entre religión y educación en las escuelas de gestión estatal. Este análisis permitió concluir que efectivamente existe una fuerte relación entre las memorias colectivas, las ideas de provincia, y el encuadramiento de la relación entre educación de gestión estatal y religión.
\end{abstract}

\section{Palabras clave}

Tesauro: Argentina, catolicismo, educación, memoria colectiva, política pública.

Referencia para citar este artículo: Prieto, María Sol. "Memorias colectivas, ideas de provincia y catolicismo en el debate parlamentario de la última ley de educación de Córdoba, Argentina (2010)". Anuario de Historia Regional y de las Fronteras 23.2 (2018): 173-198.

Fecha de recepción: 9/02/2018

Fecha de aceptación: 18/04/2018

María Sol Prieto: becaria Posdoctoral, Consejo Nacional de Investigaciones Científicas y Técnicas (CONICET), Argentina. Doctora en Ciencias Sociales, Universidad de Buenos Aires (UBA), Argentina. Magíster en Ciencia Política, Universidad Torcuato Di Tella (UTDT), Argentina. Socióloga, Universidad de Buenos Aires (UBA), Argentina. Integrante del Centro de Estudios e Investigaciones Laborales (CEIL)CONICET. Profesora de Sociología y del seminario Sociedad y Religión, UBA, Argentina. Código ORCID: https://orcid.org/0000-0002-2038-5396. Correo institucional: holasolprieto@gmail.com.

\footnotetext{
* El artículo es resultado de la investigación que realicé para mi tesis doctoral "Catolicismo y gobierno de la educación en las provincias argentinas (1999-2016)", defendida en diciembre de 2017. El trabajo de investigación para esta tesis se financió sobre todo con una beca de fin de doctorado de CONICET (20152017) y una beca doctoral de la Agencia Nacional de Promoción Científica y Tecnológica (2012-2015).
} 


\title{
Collective Memories, Ideas of Province and Catholicism in the Parliamentary Debates of the Last Education Law of Córdoba (2010)
}

\begin{abstract}
The goal of this article is to study how collective memories about the past of the Argentinian provinces are mobilized in order to create ideas of provinces that are reflected in educational public policies, particularly in relation to the link between education and religion on public schools. To fulfill this goal, a case study strategy was selected, based on the analysis of the parliamentary debate of the last education law of the province of Córdoba. On this basis, the stenographic versions of the debate in the Legislature were analyzed using content analysis technique, tracing the references of the provincial legislators to the origin and the past of the jurisdiction, to the ideas of province, and to the frame of the relationship between religion and education. This research allowed to conclude that there is a strong relation between collective memories, ideas of province and the relationship between religion and public run education.
\end{abstract}

Keywords

Thesaurus: Argentina, Catholicism, Education, Collective Memory, Public Policies.

\section{Memórias coletivas, ideias de província e Catolicismo nos debates parlamentares da última lei educativa de Córdoba (2010)}

\begin{abstract}
Resumo
O objetivo deste artigo é estudar como as memórias coletivas sobre os passados das províncias são mobilizadas e geram ideias sobre elas que se refletem nas politicas educacionais públicas, especialmente em relação ao vínculo entre a educação estadual e a religião. Para atingir este objetivo, foi selecionada uma estratégia de caso de estudo com base na análise do debate parlamentar sobre a mais recente lei de educação na província de Córdoba. As versões estenográficas deste debate foram analisadas, traçando basicamente as referências dos deputados à origem e ao passado da jurisdição, à ideia de província e ao quadro da relação entre religião e educação nas escolas de administração estadual. Esta análise permitiu concluir que existe uma forte relação entre memórias coletivas, as ideias de província e o quadro da relação entrea educação de administração estadual e religião.
\end{abstract}

Palavras-chave

Thesaurus: Argentina, catolicismo, educação, memória coletiva, política pública. 


\section{Introducción}

El mapa de los encuadramientos de la relación entre religión y educación en las escuelas de gestión estatal en Argentina es heterogéneo. Esto se debe a que Argentina es un país federal en el que la provisión de la educación es una competencia de las provincias, sobre todo a partir de la sanción en 1991 de la Ley 24.049, conocida como Ley de Transferencia de los Servicios Educativos a las Provincias, y de la Ley 24.195, en 1993, conocida como Ley Federal de Educación.

Por este motivo, las provincias pueden clasificarse analíticamente de acuerdo con el modo en el cual sus leyes de educación y sus Constituciones prescriben la presencia de la enseñanza religiosa en las escuelas estatales. Hay provincias en las que las Constituciones y leyes de educación establecen que la educación es laica, no dogmática o exenta de dogmatismos (Neuquén, Jujuy, Río Negro, Chaco, Tierra del Fuego, San Juan, Mendoza, Ciudad de Buenos Aires, Entre Ríos); provincias en las cuales esta cuestión no está definida legalmente (La Rioja, Formosa, Chubut, Corrientes, La Pampa, Santa Cruz, Misiones, Santa Fe y Buenos Aires); provincias que prescriben la enseñanza religiosa dentro del horario escolar (Salta, Catamarca, Tucumán); y provincias en las cuales la educación religiosa se puede dictar de manera optativa. En este grupo se encuentran Santiago del Estero, San Luis y Córdoba. ${ }^{1}$

Estos encuadramientos tienden a mantenerse más allá de las reformas educativas y constitucionales provinciales, aun cuando otras cuestiones relevantes de política educativa (como las estructuras de grados y niveles, por ejemplo), cambian a lo largo del tiempo. Esto es comprensible si se tiene en cuenta que la relación entre religión y educación fue, reiteradas veces, un campo de disputa en la política argentina. Una disputa no solo entre dos instituciones que intentan permanentemente proyectarse hacia la sociedad como un todo, ${ }^{2}$ como son el Estado y la Iglesia católica, sino también una disputa entre élites que, en diferentes momentos de la historia, proponen diversas ideas de nación que sustentan distintos proyectos políticos. Si bien existieron momentos claves en la historia argentina en los cuales estas diferentes ideas de nación se opusieron con más fuerza que en otros, las representaciones antagónicas surgidas al calor de estas disputas siguen permeando con fuerza los discursos políticos en Argentina. ${ }^{3}$ En estas representaciones sobre la nación, los discursos sobre el rol de lo religioso tienen un lugar central. Esto sucede

\footnotetext{
${ }^{1}$ La ley de educación cordobesa (9.780) establece en el artículo 11, inciso "d", que los progenitores tienen derecho a que sus hijos reciban de manera opcional, en el ámbito de la educación pública de gestión estatal, educación religiosa de acuerdo con sus creencias como contenido extracurricular, sin financiamiento estatal, fuera del horario de clases y a cargo de ministros autorizados de los diferentes cultos.

${ }^{2}$ Véase: Esquivel, Juan. Detrás de los muros. La Iglesia católica e tiempos de Alfonsín y Menem (1983-1999). (Quilmes: UNQ Editorial, 2004).

${ }^{3}$ Véase: Fortunato Mallimaci, El mito de la Argentina laica. Catolicismo, politica y Estado (Buenos Aires: Capital Intelectual, 2015); Gabriel Levita, "Elites políticas y nación: trayectorias sociales y representaciones sobre lo nacional de los senadores (2001-2011)" (Tesis, Doctorado en Ciencias Sociales y Sociología, UBAEHESS, 2014); Camila Perochena, "La historia en la disputa política: Los usos del pasado en el primer gobierno de Cristina Fernández de Kirchner (2007-2011)" (Tesis, Maestría en Ciencia Política, UTDT, 2016).
} 
especialmente en los temas que resultan "sensibles"4 para la Iglesia católica. La educación es uno de estos temas.

El argumento que guía este trabajo es que estas representaciones sobre el rol de la religión se articulan en memorias colectivas más amplias ${ }^{5}$ que se plasman en representaciones o ideas de provincia ${ }^{6}$ que se ponen en juego en los marcos o frames $^{7}$ a través de los cuales se piensan las políticas públicas educativas. Para rastrear este argumento se seleccionó el caso cordobés, por tratarse de una provincia en la cual se pueden observar diversas memorias colectivas de las que se desprenden distintas ideas de provincia. Este argumento requiere de aclaraciones conceptuales y metodológicas, que se explicitan a continuación.

En primer lugar, se entiende por "memoria colectiva" el concepto que propone Halbwachs, esto es, una memoria social; “[...] una corriente de pensamiento continuo, de una continuidad que no tiene nada de artificial, ya que del pasado solo retiene lo que aún queda vivo de él o es capaz de vivir en la conciencia del grupo que la mantiene". ${ }^{8}$ Un punto importante acerca de la memoria colectiva es que en su desarrollo "no hay líneas de separación claramente trazadas, como en la historia, sino simplemente límites irregulares e inciertos. El presente [...] no se opone al pasado del mismo modo que se distinguen dos periodos históricos vecinos [... $].{ }^{9}$ En otras palabras, la idea de memoria colectiva se sustenta sobre la premisa de que toda la memoria, inclusive la individual, es social y una materia viviente, dado que depende siempre de un grupo que la construye en función de su presente, sus intereses y proyecciones utópicas.

En segundo lugar, se entiende por "idea de provincia" un concepto semejante a la idea de nación de Anderson, es decir, "una comunidad política imaginada como inherentemente limitada y soberana". ${ }^{10}$ Esta comunidad política es "imaginada" porque "[...] aún los miembros de la nación más pequeña no conocerán jamás a la mayoría de sus compatriotas [...] pero en la mente de cada uno vive la imagen de su comunión". ${ }^{11}$ La nación (en este caso, la provincia) se imagina "limitada" porque "[...] incluso la mayor de ellas, que alberga tal vez a mil millones de seres humanos vivos, tiene fronteras finitas, aunque elásticas, más allá de las cuales se encuentran otras naciones". ${ }^{12}$ Se imagina "soberana" porque la soberanía política reside en ella misma

\footnotetext{
${ }^{4}$ Juan Cruz Esquivel, "Cultura política y poder eclesiástico: encrucijadas para la construcción del Estado laico en Argentina”, Archives De Sciences Sociales Des Religions 54.146 (2009): 41-59.

${ }^{5}$ Maurice Halbwachs, La memoria colectiva (Zaragoza: Prensas universitarias de Zaragoza, 2004).

${ }^{6}$ Benedict Anderson, Comunidades imaginadas. Reflexiones sobre el origen y la difusión del nacionalismo (México, DF: FCE, 1993).

${ }^{7}$ Martin Rein y Donald Schön, "Reframing policy discourse", The argumentative turn in policy analysis and planning, eds. Frank Fischer y John Forester (Durham, NC: Duke University Press, 1993) 145-166.

${ }^{8}$ Halbwachs 81

${ }^{9}$ Halbwachs 83.

${ }^{10}$ Anderson 21.

${ }^{11}$ Anderson 23.

${ }^{12}$ Anderson 25.
} 
y no en otros fundamentos exógenos (por ejemplo, divinos). Y se imagina como "comunidad" porque, independientemente de las desigualdades y enfrentamientos presentes en cada caso, la nación (en este caso, la provincia) se concibe siempre como un compañerismo profundo y horizontal.

En tercer lugar, se entiende por frame o encuadramiento en políticas públicas la manera de seleccionar, organizar, interpretar y darle sentido a la realidad para proveerla de guías de acción. Desde este punto de vista, las políticas públicas pueden estudiarse como interpretaciones que remarcan o plantean como "verdaderas" ciertas partes de la realidad en detrimento de otras y producen, en base a esa selección, una serie de prescripciones normativas. Por lo tanto, toda política pública descansa, desde esta perspectiva, en ciertas estructuras de creencias, percepciones y representaciones, denominadas marcos o encuadramientos.

Para analizar las relaciones entre memorias colectivas, ideas de provincia y encuadramientos de la relación entre educación y religión en las escuelas estatales, se eligió como abordaje metodológico el estudio de caso, debido al potencial de este tipo de investigación para, por un lado, generar descripciones densas y complejas y, por otro, desarrollar y refinar teorías. ${ }^{13}$ Se seleccionó el caso de Córdoba debido a la presencia de diversas memorias colectivas e ideas de provincia donde la tensión entre clericalismo y anticlericalismo cumple un rol especialmente relevante. ${ }^{14}$ Se decidió utilizar como fuente la versión taquigráfica del debate parlamentario sobre la última ley de educación sancionada en esta provincia. ${ }^{15}$ La selección de esta fuente obedece a que los debates legislativos cumplen con la condición de "centralidad del plenario", ${ }^{16}$ es decir, ponen a todos los legisladores en una misma situación: están condicionados por el mismo tiempo máximo para expresarse, por las mismas normas y se orientan hacia los mismos temas. En suma, la legislatura provincial es la unidad de recolección de datos y la versión taquigráfica del debate es la fuente. La técnica seleccionada para esta investigación fue el análisis del discurso, más específicamente, el análisis de contenido. ${ }^{17}$

Finalmente, las dimensiones analizadas teniendo en cuenta este abordaje y el entorno conceptual fueron las referencias al origen o al pasado de la provincia que aparecieron en el debate; las referencias a ideas de provincia; y las referencias al encuadramiento de la relación entre religión y educación, especialmente aquellas vinculadas a la inclusión o no de enseñanza religiosa en las escuelas estatales. Las tres dimensiones son analizadas en el siguiente apartado, que también incluye una descripción del

\footnotetext{
${ }^{13}$ John Gerring, "What Is a Case Study and What Is It Good for?, American Political Science Review 98. 2 (2004): 341-354.

${ }^{14}$ Roberto Di Stefano, Ovejas negras. Historia de los anticlericales argentinos (Buenos Aires: Sudamericana, 2010).

${ }^{15}$ Legislatura de la provincia De Córdoba (LPC). Cuerpo De Taquígrafos. $49^{\circ}$ Reunión. $45^{\circ}$ Sesión Ordinaria. 15 de diciembre de 2010. Versión Taquigráfica: en adelante, "VT".

${ }^{16}$ Gary Cox, "The organization of Democratic Legislatures", The Oxford Handbook of Political Economy, eds. Barry Weingast y Donald Wittman (Oxford: Oxford University Press, 2006).

${ }^{17}$ Irene Vasilachis de Gialdino, Estrategias de investigación cualitativa (Barcelona: Gedisa, 2006).
} 
contexto sociopolítico en el que se dio el debate. Los resultados de este análisis son evaluados en una reflexión final (apartado 3).

\section{Análisis empírico: "Córdoba, entre la tradición y la modernidad"}

Las memorias colectivas presentes en el debate sobre la última ley de educación cordobesa constituyen, ante todo, un relato sobre un antagonismo o división. A partir de estas memorias se monta la idea de una provincia dividida o, como marcaron muchos legisladores, "crispada" por la decisión de si se debía incluir o no la enseñanza religiosa en las escuelas estatales. A diferencia de otras provincias en las cuales hay un grupo mayoritario que recuerda y señala como elementos externos a ese grupo a quienes no recuerdan de la misma manera, en Córdoba son grupos contendientes los que construyen memoria colectiva.

Estos grupos identifican el origen de "lo cordobés" en diferentes hitos de memoria: el pasado hispánico y católico del Virreinato del Perú, por un lado, y la Reforma Universitaria de 1918 y el movimiento reformista, por otro. Dada la propia definición de grupo vinculada a la idea de memoria colectiva, los grupos que recuerdan no son de ninguna manera esenciales, es decir, no son una sumatoria de individuos empíricos, sino que, por el contrario, lo que los define como grupos es la existencia de un relato sobre su historia sobre el cual existen "testimonios". ${ }^{18}$ En ese relato existen personas y voces autorizadas para narrar y recrear la memoria colectiva, en lo que Hervieu-Léger ${ }^{19}$ denomina un "linaje" y los autores que estudiaron el caso cordobés ${ }^{20}$ denominan a menudo "tradición".

En Córdoba, el antagonismo entre nacionalismo católico cordobés (en adelante, NCC) ${ }^{21}$ y liberalismo fue la base sobre la cual se articularon memorias colectivas, ideas de provincia y marcos de políticas públicas antagónicos. El origen de este antagonismo se remite al período de surgimiento del Virreinato del Río de la Plata y se sitúa más concretamente en el período de conformación del Estado nacional. El desgajamiento del Virreinato del Perú desplazó a Córdoba del centro político, económico y religioso del territorio de lo que luego fue la Argentina, ${ }^{22}$ por dos motivos. Primero, por el

\footnotetext{
${ }^{18}$ Danièle Hervieu-Léger, La religion, hilo de memoria (Barcelona: Herder, 2005) 137. La noción de "testimonio" de Hervieu-Léger refiere a determinados hitos (pueden ser textos, elementos materiales o incluso sucesos) que funcionan como "pruebas" del relato de memoria, más específicamente de la pertenencia de quien enuncia dicho relato al grupo que recuerda y de la continuidad y existencia de dicho grupo.

${ }^{19}$ Danièle Hervieu-Léger, El Peregrino y el convertido. La religión en movimiento (México D. F: Ediciones del Helénico, 2004).

${ }^{20}$ Véase Alfredo Terzaga, "Clericalismo y liberalismo: dos caras de la medalla cordobesa", Todo es Historia. 75 (1973): 70-84; José Aricó, “Tradición y modernidad en la cultura cordobesa”, Revista Plural 4.13 (1989): 10-14.

${ }^{21}$ Silvia Roitemburd, "Educación y control social. El nacionalismo Católico Cordobés (1862-1944)", Historia de la educación en la Argentina IV. La educación en las provincias y los territorios nacionales (1885-1945), Dir. Adriana Puiggrós (Buenos Aires: Galerna, 1993) 59-119.

22 Mina Navarro, "La antinomia tradición / modernidad en los intelectuales de la Reforma Universitaria de Córdoba en 1918. Un análisis desde la geopolítica histórica argentina”, Andamios. Revista de Investigación
} 
carácter de ciudad cabecera que adquirió Buenos Aires en detrimento de Córdoba y otras provincias como producto del plan reformista de la Corona española, que buscó transformarse en un imperio comercial, siguiendo el ejemplo de Gran Bretaña. ${ }^{23}$ Segundo, por la expulsión de los jesuitas y el creciente peso que comenzó a adquirir el clero secular, con mayor presencia en Buenos Aires, en detrimento del regular. ${ }^{24}$ Esta dislocación operó como un primer factor diferenciador entre las élites cordobesas y del noroeste, por un lado, y las porteñas, por otro, en relación al vínculo con la religión: las primeras más influidas por las prácticas y postulados pre-reformistas, y las segundas más vinculadas a las reformas borbónicas. ${ }^{25}$ A partir de la década revolucionaria, ${ }^{26}$ las normas religiosas y a la vez políticas que antes hacían cumplir delegados de la Inquisición en América Latina se mantuvieron aunque con diferentes grados de intensidad: en Buenos Aires las sanciones a crímenes religiosos tales como la blasfemia o la brujería dejaron de aplicarse, mientras que en Córdoba dichos "delitos" continuaron siendo perseguidos. ${ }^{27}$ Esta diferencia en la persistencia de las instituciones y normas pre-reformistas hizo que una parte importante de la élite cordobesa mantuviera una cultura política más vinculada a las normas, valores e instituciones de la Iglesia católica.

A fines del siglo XIX, esta diferencia entre las élites porteñas y cordobesas se tradujo en un antagonismo entre élites dentro de Córdoba. Cuando el mitrismo ingresó a esta provincia, considerada "la llave del interior", lo hizo en alianza con sectores liberales de la élite cordobesa. Como consecuencia, surgió una resistencia de las élites locales opositoras a Mitre ${ }^{28}$ y, en términos generales, al Estado Nacional conducido por Buenos Aires, ${ }^{29}$ que se dio en clave de nacionalismo católico. De este modo surgió un discurso que "desde la definición de la identidad nacional=Nación Católica, integró en forma subordinada los reclamos del NCC". ${ }^{30}$ La "contraofensiva eclesiástica" ${ }^{31}$ no fue, por lo tanto, un fenómeno únicamente eclesiástico sino que, por el contrario, expresó el malestar de las élites tradicionales de la provincia, las cuales procuraron defender la "autonomía" frente Buenos Aires en clave de "verdadera identidad nacional". Este discurso se construyó sobre un sistema de equivalencias según el cual "Iglesia Católica $=$ Interior $=$ Valores Dogmáticos $=1$ o verdadero $=10$ inmutable" ${ }^{32}$ Esta cadena

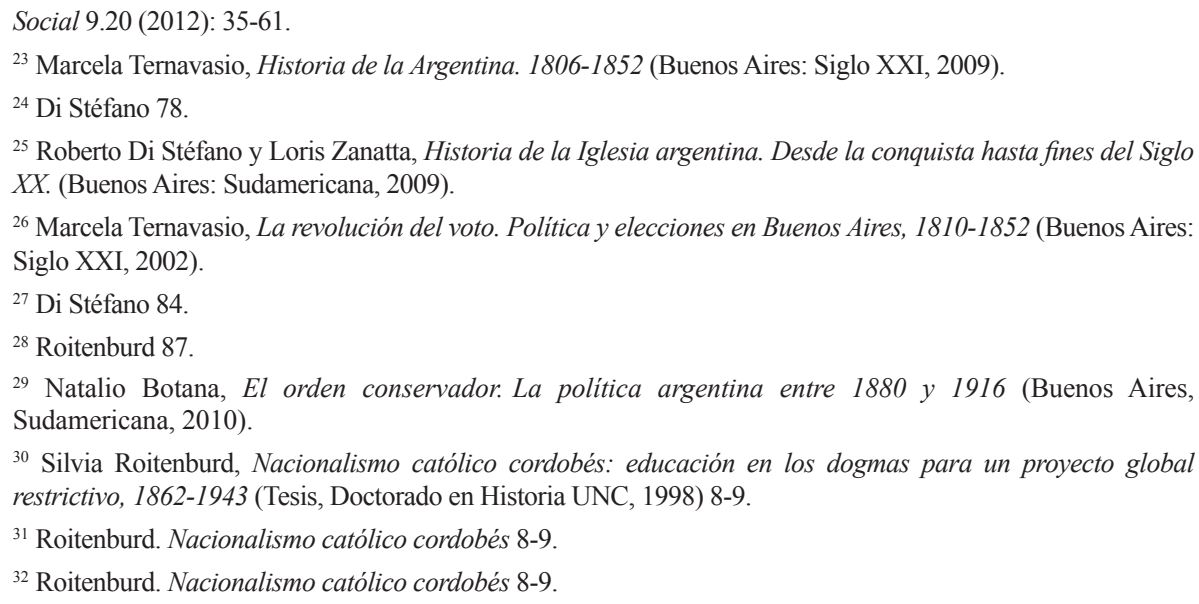


equivalencial se centraba en el antagonismo con Buenos Aires y la pretensión de la clase política del eje porteño de controlar la unidad del país. De este modo, el discurso del NCC trazó una cadena equivalencial para designar al campo enemigo según la cual "liberalismo $=$ Buenos Aires $=$ cosmopolitismo $=$ lo transitorio $=$ tolerancia religiosa y cultural = la revolución". ${ }^{33}$ El liberalismo, por su parte, opuso a esta formación discursiva una similar, pero invertida en el valor otorgado a cada cadena. En este sentido, tal como lo recuerda Abratte, ${ }^{34}$ Sarmiento caracterizó a Córdoba como "la Atenas de la barbarie docta".

La efectividad de estos discursos se debió al contexto en el cual emergieron, caracterizado por los conflictos entre un centro que se proyectaba como un foco de civilización y un interior al cual este centro caracterizaba como un resabio o bien de la barbarie o bien, como en el caso cordobés, de la Edad Media. Este discurso liberal, fuertemente anticlerical, encontró eco en varios sectores de la élite cordobesa. La tesis de Ramón Cárcano y el conflicto que originó con el vicario Clara que culminó en la expulsión del nuncio apostólico Luis Matera en 1884, ${ }^{35}$ así como los normalistas cordobeses laicos que apoyaron la iniciativa sarmientina de crear una escuela normal en esa provincia, pueden leerse en esta clave. ${ }^{36} \mathrm{El}$ discurso del liberalismo cordobés, coincidente en varios puntos con el del liberalismo porteño, volvió a con fuerza en el discurso de los reformistas de 1918.

El discurso reformista, centrado en la autonomía de la universidad, la participación de los estudiantes en el gobierno de la institución, el laicismo como criterio para la selección de contenidos y la "extensión universitaria", se convirtió en poco tiempo en una doctrina sistemática sobre la universidad en Argentina. ${ }^{37}$ Pero además trascendió las fronteras de la universidad en tres sentidos. Primero, porque más allá del discurso sobre el cogobierno docente-estudiantil, el discurso de la Reforma implicó también una noción de democracia ampliada bajo el lema de "participación" que contrastaba con la definición del NCC, que asimilaba la democracia al caos y la anarquía. ${ }^{38}$ Segundo, porque los intelectuales reformistas, como Saúl Taborda y Antonio Sobral, tradujeron el programa universitario en clave de reforma educativa y cultural. ${ }^{39}$ Tercero, porque varios cuadros políticos y el propio discurso de la reforma nutrieron, 18 años después, al movimiento político dentro de la UCR encabezado por Amadeo Sabattini. ${ }^{40}$

\footnotetext{
${ }^{33}$ Roitenburd. Nacionalismo católico cordobés 8-9.

${ }^{34}$ Juan Pablo Abratte, "Las huellas de la ley 1.420 en la Provincia de Córdoba: Legislación educativa y enseñanza religiosa en perspectiva histórico-política", Historia de la educación-anuario 16.1 (2015): 25-38.

${ }^{35}$ José Ghio, La Iglesia Católica en la política argentina (Buenos Aires, Prometeo, 2007).

${ }^{36}$ Adriana Puiggrós, Sujetos, disciplina y curriculum: en los orígenes del sistema educativo argentino, Vol. 1. (Buenos Aires: Galerna, 1990).

${ }^{37}$ Silvia Sigal, Intelectuales y poder en Argentina: la década del sesenta (Buenos Aires: Siglo XXI, 2002).

${ }^{38}$ Fortunato Mallimaci, "El Catolicismo. Entre el liberalismo integral y la hegemonía militar (1900-1960)”, 500 años de cristianismo en Argentina, María Liboreiro y otros (Buenos Aires: Centro Nueva Tierra, 1992) 197-365.

${ }^{39}$ Véase Juan Pablo Abratte, Hegemonía, reforma y discurso educativo en la provincia de Córdoba (1984-1999) (Tesis, Doctorado Flacso Argentina, 2007); César Tcatch, "Movimiento estudiantil e intelectualidad reformista en Argentina (1918-1946)", Cuadernos de historia (Santiago) 37 (2012): 131-157.

${ }^{40}$ César Tcatch, Sabattinismo y peronismo: partidos políticos en Córdoba, 1943-1955 (Buenos Aires: Biblos, 2006).
} 
Tiempo después, en la última transición democrática, ${ }^{41}$ el discurso bienestarista y democrático del sabattinismo fue recuperado por el candidato a la Gobernación de Córdoba Eduardo Angeloz. El angelozismo adaptó a la realidad provincial el quiebre discursivo del alfonsinismo con el pasado inmediato violento de la Argentina. Este quiebre asociaba al peronismo con el pasado y la violencia y proponía a la UCR como refundadora de una república pacífica. ${ }^{42}$ Angeloz vinculó este discurso refundador con la tradición reformista cordobesa. En palabras de Abratte:

[...] el angelozismo se constituyó como identidad política: la construcción de una frontera (en tanto que relación antagónica entre 'nosotros' y 'ellos') se produjo mediante la condensación de elementos propios del discurso alfonsinista; el antagonismo autoritarismo vs. democracia permitió definir una identidad política y excluir a sectores de la oposición (particularmente al Peronismo) como $\cdot$ no democráticos. ${ }^{43}$

En ese marco sucedieron primero la Reforma Educacional de Córdoba, donde se configuró un discurso educativo oficial en el cual el discurso político y pedagógico del angelozismo fueron condensados; ${ }^{44}$ y luego la Ley de Educación 8113, con la cual el gobierno cordobés buscó adelantarse a la Ley Federal creando mayores márgenes de maniobra educativa para la provincia en calidad de resguardo respecto a las políticas nacionales.

Este breve repaso sobre la conformación de dos grupos de memoria o, en términos de los especialistas cordobeses, dos tradiciones ${ }^{45}$ o polos de una antinomia, ${ }^{46}$ es relevante para comprender el debate parlamentario de la última ley de educación.

\subsection{Contexto de la discusión parlamentaria y debate público social}

En 2010, cuando se debatió la ley de educación, el Gobierno de la provincia de Córdoba estaba en manos de Unión por Córdoba (UPC). Esta alianza, encabezada por el peronismo, gobierna la provincia desde 1999 y está conformada por el Partido Justicialista (PJ), la Unión de Centro Democrático (UCeDé), de tendencia liberal, el partido provincial Acción para el Cambio (APEC) y el Partido Demócrata Cristiano de Córdoba. Dado que en Córdoba el catolicismo funciona en gran medida como una

\footnotetext{
${ }^{41}$ En este trabajo se entiende por "última tradición democrática” el período que va desde fines de 1982 hasta el célebre “Juicio a las Juntas” en 1985. Sobre este período, véase: Guillermo O’Donnel; otros, Transiciones desde un gobierno autoritario. América Latina (Buenos Aires, Paidós, 1988) y Gerardo Aboy Carlés, Las dos fronteras de la democracia argentina. La redefinición de las identidades politicas de Alfonsín a Menem (Rosario: Homo Sapiens, 2001).

${ }^{42}$ Gerardo Aboy Carlés, "Populismo y democracia en la Argentina contemporánea. Entre el hegemonismo y la refundación”, Estudios Sociales 28 (2005): 125-149.

${ }^{43}$ Juan Abratte, Hegemonía 76.

${ }^{44}$ Juan Abratte, Hegemonía 76.

45 Terzaga $70-84$.

${ }^{46}$ Saúl Taborda, Investigaciones Pedagógicas. Volumen Iy II (Córdoba: Ediciones Ateneo Filosófico de Córdoba, 1951).
} 
"religión pública", ${ }^{47}$ el gobierno de UPC, sobre todo en la cartera educativa, se nutrió de militantes católicos (de movimientos católicos como Fraternidad de Agrupaciones Santo Tomás de Aquino, FASTA, también de Palestra y Acción Católica) para gobernar la educación, sobre todo entre 1999 y 2007 . Pero a la vez, debido a la cercanía entre el peronismo y el principal sindicato docente (Unión de Educadores de la Provincia de Córdoba, UEPC), la cartera educativa sumó también a cuadros provenientes del sindicalismo docente, sobre todo desde 2007, cuando el dirigente sindical docente Walter Grahovac se hizo cargo del Ministerio de Educación.

Al momento de la discusión de la ley, la oposición en la Legislatura cordobesa (donde el gobierno tenía la mayoría) estaba liderada por la Unión Cívica Radical de esa provincia, aunque también integraban la Legislatura otros partidos de centro-derecha (PRO), de centro-izquierda (Nuevo Encuentro, Libres del Sur y el Frente Cívico) y de izquierda (Partido Obrero e Izquierda Socialista). Pero más allá de la oposición legislativa, que no tenía la mayoría, el proceso de discusión pública-social de la última ley de educación se caracterizó por tener un alto grado de conflictividad, sobre todo estudiantil.

Los primeros avances en el diseño de la ley provincial de educación de Córdoba ocurrieron en $2009,{ }^{48}$ pero la primera mención política al respecto fue recién en febrero del $2010^{49}$ cuando Grahovac anunció que ese año se debatiría con los distintos actores de la comunidad educativa una ley de Educación nueva adaptada a la ley nacional, de acuerdo con lo pautado por el Consejo Educativo de esa provincia. Desde ese primer momento, el ministro definió un límite temporal claro: afirmó que la ley debía ser sancionada a fines de ese año. A la vez, este anuncio implicaba una representación institucionalizada y mediatizada de lo que significaba la participación estudiantil, la cual chocó con las representaciones del movimiento estudiantil cordobés, el cual concebía la participación política como participación directa.$^{50}$ Esto derivó, meses después, en uno de los conflictos estudiantiles más importantes de la Argentina en los últimos años. La confluencia entre, por un lado, las intenciones del Ejecutivo de impulsar la nueva ley y conducir la participación de un modo que los estudiantes consideraron restrictivo y, por otro lado, la respuesta de los estudiantes a este posicionamiento, obligaron al ministro y a la Legislatura a ampliar este debate, dándole a todo este proceso un carácter de negociación entre la iniciativa del Ejecutivo y la demanda de mayor participación.

\footnotetext{
${ }^{47}$ Sobre "religión pública" véase: José Casanova, "Religiones públicas y privadas", Caja de Herramientas, Dir. Javier Auyero (Buenos Aires: UNQ, 1999). Sobre el catolicismo como religión pública en Córdoba véase: María Sol Prieto, "Catolicismo y gobierno de la educación en las provincias argentinas (1999-2016)" (Tesis, Doctorado en Ciencias Sociales, UBA, 2017).

${ }^{48}$ Daniel Míguez y Andrés Hernández, "Los sentidos de la democracia y la participación. Un estudio de caso sobre la toma de escuelas en Córdoba durante 2010”, Revista del Museo de Antropología 9.1 (2016): 95-106.

${ }^{49}$ Gabriela Lamelas, "El debate sobre educación laica-religiosa en el marco de la Reforma de la Ley 8113/91 en 2010. Abordaje de un recorrido histórico", Sintesis. Artículos basados en tesinas de grado 4.4 (2013): 1-23.

${ }^{50}$ Míguez y Hernández 98.
} 
Desde un primer momento el catolicismo estuvo presente en la redacción y el debate de la ley. Sin embargo, esta participación no fue directamente de la Iglesia católica institucional; no fueron los obispos quienes defendieron las posiciones de la Iglesia. En Córdoba, la pieza clave en garantizar una redacción que estuviera acorde con las aspiraciones de la Iglesia católica fue un funcionario, Carlos Alberto Sánchez, quien tiene una larga trayectoria como militante católico de FASTA. ${ }^{51}$ El Consejo Católico de Educación de Córdoba (CCEC) también participó de esta primera redacción. ${ }^{52}$ Durante el año el tema no tuvo demasiada relevancia en la esfera pública e incluso se realizó una primera jornada de debate en las escuelas en la que no hubo demasiada participación ni por parte de los docentes ni por parte de los estudiantes secundarios. ${ }^{53}$ Esto cambió el 29 de septiembre cuando los alumnos tomaron tres colegios importantes de la ciudad de Córdoba (el IPEM 38 Colegio Jerónimo Luis de Cabrera, el IPEM 270 Manuel Belgrano y la Escuela Superior de Comercio Manuel Belgrano, dependiente de la Universidad Nacional de Córdoba). Las demandas estaban centradas en dos puntos: las malas condiciones edilicias y la necesidad de ampliar el debate de la Ley de Educación. ${ }^{54}$ El 30 de diciembre se sumó la Escuela Normal Superior Alejandro Carbó y, en solidaridad, una facultad de la Universidad Nacional de Córdoba (UNC). En los 20 días siguientes se tomaron 16 escuelas secundarias más, algunas primarias y pocos terciarios..$^{55}$

A pesar de que las primeras tomas de colegios se hicieron como respuestas a los problemas edilicios, a lo largo del conflicto, la consigna estudiantil de "una educación laica", que apareció en el segundo día de tomas, comenzó a articular a las demás demandas (mejora edilicia y mayor participación directa de los estudiantes en el debate). ${ }^{56}$ Los artículos del anteproyecto que estaban puestos en discusión por esta consigna estudiantil eran el 11 inciso "e" y el 35 inciso "c". El primero permitía la incursión de la enseñanza religiosa de manera optativa en las escuelas estatales, el segundo incluía la enseñanza religiosa entre los aprendizajes fundamentales. Si bien el derecho de los padres a elegir la educación religiosa para sus hijos (Art. 11 Inc. e) ya estaba previsto en la ley anterior, los alumnos pretendían, de máxima, que este artículo no fuera incluido y, de mínima, que al rótulo de "opcional" se le agregara “extracurricular”. El Artículo 35, en cambio, debía ser abolido en su totalidad debido a que, al incluir la educación religiosa dentro los "aprendizajes fundamentales" enunciados en la Ley, podía representar eventualmente un problema para interpretar la cuestión de la "opcionalidad" de la educación religiosa. ${ }^{57}$

\footnotetext{
${ }^{51}$ Entrevista de María Sol Prieto a Carlos Alberto Sánchez, Córdoba, Argentina, mayo de 2016.

${ }^{52}$ Lamelas 12.

${ }^{53}$ Andrés Hernández, “'No somos el futuro, somos el presente' -política, autoridad y acción colectiva en el espacio escolar-", Revista Cuestiones de Población y Sociedad 3.3 (2013): 159-162.

54 “Estudiantes ratifican las protestas y las tomas de los colegios", La Voz del Interior, (Córdoba) 29 de septiembre de 2010.

${ }^{55}$ Mariana Beltrán y Octavio Falconi, "La toma de escuelas secundarias en la ciudad de Córdoba: condiciones de escolarización, participación política estudiantil y ampliación del diálogo social”, Propuesta Educativa 35.20 (2011): 27-40.

${ }^{56}$ María Prieto 152-165.

${ }^{57}$ Juan Pablo Abratte, "Leyes, políticas y educación en Cordoba: algunas reflexiones en torno a la trayectoria de la legislación educativa provincial en una perspectiva histórico-política", Historia, política y reforma educativa:
} 
Luego de un largo proceso de tensa negociación (marcada por tomas de establecimientos y movilizaciones callejeras) en la que el Ministerio de Educación debió iniciar las reformas edilicias, convocar a una segunda jornada de debate en las escuelas y convocar a cuatro audiencias públicas en distintas localidades de la provincia, los legisladores anunciaron que incorporarían al texto del anteproyecto que la educación religiosa opcional sería extracurricular, fuera del horario escolar y dictada por ministros de los diferentes cultos, de modo que no comprometería ningún tipo de financiamiento específico del Estado provincial. Al mismo tiempo, decidieron eliminar la educación religiosa de los aprendizajes fundamentales comprendidos en el Art. 35 Inc. "c". En un mismo sentido, consensuaron modificar el artículo referido a la educación sexual. En ese artículo se establecía que uno de los objetivos de la educación era "brindar conocimientos y promover valores que fortalezcan la formación integral de una sexualidad responsable" y los legisladores acordaron agregar que dichos conocimientos se brindarían en los términos de Ley Nacional de Educación Sexual Integral. ${ }^{58}$ Es importante marcar que en las audiencias públicas aparecieron reiteradamente discursos que apelaban a movilizar las memorias colectivas sobre la Reforma de 1918 como hito laico y sobre el Cordobazo como hito de participación estudiantil. ${ }^{59}$ Este tipo de discursos volvió a aparecer en el debate parlamentario, que será analizado en los próximos subapartados. Finalmente, la ley se aprobó con 43 votos a favor y 25 en contra mientras los disturbios afuera de la legislatura fueron muchos y graves debido a que los estudiantes convocaron a una movilización en el día de la sesión.

\subsection{Memoria del pasado cordobés: una memoria de la división}

Del análisis de las memorias colectivas presentes en el debate de la última ley de educación se destacan sobre todo dos cuestiones. Por un lado, la caracterización de dicha memoria como una memoria partida en dos. Por otro lado, la reivindicación de la tradición liberal reformista y luego angelozista, de la cual la Ley 8113 es presentada como un testimonio y un hito de memoria.

Una de las formas en las cuales aparece la idea de la memoria colectiva cordobesa como una memoria dividida es la vinculación de esta a una historia atravesada por la disputa entre élites conservadoras con una idea restrictiva de la política, por un lado, y movimientos contestatarios encabezados o bien por facciones reformistas de las élites o bien por sindicatos clasistas y otros sectores de izquierda, por otro. De acuerdo con esta lectura, en Córdoba coexisten sectores conservadores que defienden intereses minoritarios, junto a movimientos populares y de vanguardia que, cíclicamente, pretenden movilizar o poner en crisis un orden al que perciben como opresivo y excluyente.

Aportes críticos, transformaciones culturales y perspectiva en el espacio educativo argentino, Dir. Silvia Roitenburd y Juan Pablo Abratte (Córdoba: UNC, 2016).

58 "La educación religiosa estará incluida en la ley", La Voz del Interior, (Córdoba) 14 de diciembre de 2010.

${ }^{59}$ María Prieto 152-165. 
Esta caracterización está vinculada a la memoria colectiva sobre los orígenes de Córdoba como provincia en el marco de la conformación de la Argentina como Estado-Nación. En esta memoria, Córdoba es representada como una herencia de la Edad Media y no de la barbarie, como las demás provincias del interior. En Facundo $^{60}$ Sarmiento pinta a Buenos Aires como una ciudad culta y progresiva que contrasta con un interior bárbaro y atrasado, aunque distingue a Córdoba del resto de las provincias: la presencia de doctores, sacerdotes, una universidad y múltiples instituciones funcionando desde la época colonial lo obligan a trazar una línea entre la "barbarie" del interior y la tradición de "la Docta" ${ }^{61}$ La respuesta a este dilema fue contraponer a la "moderna" Buenos Aires la figura de una Córdoba "medieval". ${ }^{62}$ En la misma clave, José Ingenieros afirma que esta provincia "sintetiza el pensamiento hispanocolonial". ${ }^{63}$ Retomando este debate, el intelectual reformista Arturo Orgaz planteó que Córdoba y Buenos Aires son, a la vez que provincias, símbolos que Sarmiento utilizó para representar "la lucha entre la mentalidad feudal (siglo xII) y la mentalidad moderna (siglo XIX)" ${ }^{64}$ Tiempo después, Aricó ${ }^{65}$ caracterizó a Córdoba como a una "ciudad de frontera" moldeada en base a la oposición irreductible entre tradición y modernidad.

Esta idea de que hay una memoria dividida sobre el pasado que se traduce en una comunidad política dividida que debe superar estos antagonismos, estuvo presente explícitamente en varias intervenciones del debate, ${ }^{66}$ en lo que constituye una memoria colectiva como memoria de la división:

Voy a hablar sobre Córdoba, como brillantemente lo ha sostenido, allá por los años '60, José María Aricó, del grupo "Pasado y Presente": Se ha movido históricamente, "entre la tradición y la modernidad", Córdoba de las Campanas, también revulsiva y contestataria; se ha movido entre el conservadurismo ostensible que ha articulado poderes que han pretendido hacer invisible su poder, sin lograrlo; por caso, los grupos concentrados de la economía y la propia Iglesia, se han encontrado frente al sentido pugnado por la contestación y la revuelta, por las luchas populares, de los que son claros exponentes la Reforma Universitaria y el Cordobazo. ${ }^{67}$

\footnotetext{
${ }^{60}$ Domingo Sarmiento, Facundo (Villa María: Eduvim, 2009).

${ }^{61}$ En este ensayo, Sarmiento califica a Córdoba como "española por educación literaria y religiosa, estacionaria y hostil a las innovaciones revolucionarias" y la contrapone a "Buenos Aires, todo novedad, todo revolución y movimiento". Sarmiento 191.

${ }^{62}$ Terzaga $70-84$.

${ }^{63}$ José Ingenieros, Las direcciones filosóficas de la cultura argentina (Buenos Aires: El Aleph, 2000) 13.

${ }^{64}$ Arturo Orgaz, Sarmiento y el naturalismo histórico (Córdoba: Imprenta Rossi, 1940) 306-307.

${ }^{65}$ Aricó 10-14.

${ }^{66}$ Véase: Dip. Coria, VT, 166; "El conflicto entre laicismo y clericalismo en el ámbito educativo ha sido una constante en la historia de Córdoba", Dip. Genesio de Stabio, VT, 101.

${ }^{67}$ Dip. Coria, VT, 153. Es importante destacar que la diputada Adela Coria era representante por el partido de nueva izquierda Nuevo Encuentro, el cual tenía en aquel entonces estrechos vínculos con la Facultad de Filosofía y Humanidades de la UNC. En dicha Facultad, Coria es profesora titular DS de la cátedra Didáctica General de la Escuela de Ciencias de la Educación de la Facultad de Filosofía y Humanidades de la Universidad Nacional de Córdoba (entre varios cargos docentes más). Además, Coria es doctora en Ciencias con Especialidad en
} 
Esta memoria de la división se complementa con una memoria que se reconoce en uno de los grupos que recuerda y se constituye a partir su relato sobre el pasado. Este grupo está identificado con un lenguaje y una serie de hitos de memoria que le son propios: se trata un linaje liberal que se reconoce primero en la década de 1880 en intelectuales como Cárcano, y que fue reactualizado y reconfigurado primero por la Reforma de 1918 en clave universitaria y política, luego por el sabattinismo en clave estatal y cultural y finalmente por el angelozismo, en clave democrática. ${ }^{68}$ Estos hitos de memoria pueden observarse en varias intervenciones, ${ }^{69}$ de las cuales es especialmente llamativa una en la cual un legislador de la Unión Cívica Radical con pasado reformista en su militancia universitaria utiliza el verbo recordar, en una acción del habla que refiere, justamente, a la noción de memoria colectiva:

[...] Recuerdo la Ley 1420, sancionada en julio de 1884 [...] en aquel histórico debate donde las bancadas liberales [...] terminaron alumbrando esta ley fundacional [...]. También recuerdo cuando hace 92 años los estudiantes cordobeses, con Deodoro Roca a la cabeza, encendieron la llama de la Reforma Universitaria [...] Recuerdo el Congreso Pedagógico Nacional, [...] como una extraordinaria demostración de participación popular y ciudadana[...].Recuerdo la participación que hubo en cada uno de los pueblos de la Provincia de Córdoba y de la República Argentina, y recuerdo mi participación en los talleres en mi vieja y querida Escuela Nacional de Comercio de Río Cuarto [...].Más cerca todavía, me parece que corresponde destacar en este breve recorrido por la historia educativa de la Nación el proceso de la "carpa blanca"[...] ¿Por qué hago este repaso?, ¿por qué traigo esta cronología [...]? Porque todos tienen un común denominador: todos y cada uno de estos procesos fueron precedidos por una historia de lucha, de resistencia y de profunda participación popular y ciudadana. ${ }^{70}$

En este discurso están presentes en una misma línea de continuidad dos tipos de memoria colectiva: la memoria histórica y la autobiográfica. El diputado dice recordar la sanción de la Ley 1420 y la Reforma Universitaria, dos hechos que no vivió de manera directa pero que sí fueron vividos por el grupo que recuerda. Esto explica que el diputado vincule estos hechos con otros que sí vivió, como el Congreso Pedagógico de 1984, en una continuidad. Es esta continuidad la que permite hablar de un grupo de memoria, del cual el legislador se siente parte. Un punto que marca el carácter específico o limitado de este grupo que recuerda es que la Ley 1420 nunca se aplicó en Córdoba. Al contrario, ante la sanción de dicha Ley, que quitaba la educación religiosa del horario de clase en las escuelas estatales, el NCC se abroqueló en torno a la enseñanza religiosa, ${ }^{71}$ reivindicándola como un símbolo de autonomía ante Buenos

\footnotetext{
Investigación Educativa.

${ }^{68}$ Juan Pablo Abratte, Hegemonía 178.

${ }^{69}$ Dip. Campana, VT, 178; Dip. Pozzi, VT, 51.

${ }^{70}$ Dip. Birri, VT, 173-174.

${ }^{71}$ La Ley de Educación Común y Obligatoria 1426, de 1896, incluyó en el artículo 3 "la formación del carácter de los niños por la enseñanza religiosa". Gabriela Lamelas, "La invención de una tradición educativa. Disputas en torno al proceso de regulación normativa de la enseñanza de la religión en las escuelas públicas de Córdoba (1896-1923)", Historia, política y reforma educativa: Aportes críticos, transformaciones culturales y perspectiva en el espacio educativo argentino, Dir. Silvia Roitenburd y Juan Pablo Abratte (Córdoba: UNC, 2016).
} 
Aires al que las jerarquías eclesiásticas llamaron "resistencia".72 Otra cuestión importante presente en este discurso es la idea de la "profunda participación popular y ciudadana". La idea de la participación forma parte, como lo marqué en la introducción del caso, de la cadena equivalencial propia del discurso liberal-reformista cordobés: fue uno de los principales emblemas de la Reforma de 1918 y uno de los núcleos de la propuesta política y pedagógica de Taborda. En el caso de la discusión de esta ley la cuestión de la participación apareció numerosas veces asociada tanto a la memoria colectiva como a la idea de provincia.

En relación con este tema, se observa que otro hito en la memoria liberal-reformista cordobesa es la Ley 8113 la cual, como lo marqué anteriormente, consistió en un mecanismo para ampliar los márgenes de autonomía cordobesa ante la entonces inminente sanción de la Ley Federal de Educación. Respecto a la sanción de esta ley circularon tres discursos en el debate de la última ley de educación. El primer discurso consiste en la reivindicación, por parte de los radicales, de dicha ley. La sanción de esta ley es construida por los radicales como un hito de memoria porque los diputados peronistas no la acompañaron en 1991, cuando el gobierno radical la propuso. Este momento es recuperado en los discursos casi 20 años después, cuando son los diputados radicales quienes no acompañarán un proyecto de ley de educación promovido por un gobierno peronista. De este modo, se constituye una memoria colectiva que explica el presente del grupo que recuerda. En este sentido, la Ley 8113 funciona como un testimonio. ${ }^{73}$

El segundo discurso enfatiza la "participación popular" presente en la elaboración y la sanción dicha ley, y la contrasta con lo que se considera un bajo nivel de participación del proyecto que se debate en la sesión, explicando también el presente. Desde este punto de vista, también se toma a la Ley 8113 como un testimonio. Primero, porque funciona como una evidencia de que la participación es un componente identitario central del radicalismo cordobés que lo distingue del peronismo. Segundo, porque al reconocer a la Ley 8113 como un testimonio de que la participación es un componente central en la identidad radical, ser coherentes con dicho testimonio implica no apoyar el proyecto de ley que se está debatiendo en el recinto. ${ }^{74}$

Por último, hay una mención de la Ley 8113 que se corresponde con una memoria más histórica, es decir, más externa a los grupos que recuerdan, que explica a la Ley 8113 como una negociación entre "sectores cercanos a posiciones de defensa de un rol subsidiario y de inclusión de la enseñanza religiosa en la escuela pública" y "sectores que defendían el laicismo y la principalidad del estado en materia educativa". ${ }^{75}$

\footnotetext{
${ }^{72}$ Véase: Lamelas 159; Silvia Roitenburd, Nacionalismo católico Cordobés (1862-1943): educación en los dogmas para un proyecto global restrictivo (Córdoba: Ferreyra Editor, 2000) 98.

${ }^{73}$ Dip. Pozzi, VT, 137-138; Dip. Rossi, VT, 54.

${ }^{74}$ Dip. Pozzi, VT, 38-39.

${ }^{75}$ Dip. Coria, VT, 155.
} 
En suma, en los discursos del debate de la ley de educación cordobesa se pueden encontrar dos memorias: una que identifica la memoria de la comunidad política cordobesa como una memoria de la división, y otra vinculada a uno de los grupos que recuerda, el liberalismo-reformismo-sabattinismo-angelozismo, para el cual la Ley 8113 fue un hito de participación de la sociedad cordobesa.

\subsection{Ideas de provincia en Córdoba: una provincia dividida}

Las ideas de provincia presentes en el debate legislativo sobre la ley de educación en Córdoba estuvieron muy relacionadas con las memorias colectivas. De modo que, así como se identificaron dos grupos que recuerdan, se pueden identificar también dos ideas de provincia que difieren entre sí. A grandes rasgos, una que ve a Córdoba como una provincia tradicional, católica, jerárquica y poco abierta a la diversidad religiosa y otra que ve a Córdoba como una provincia moderna, secular, democrática y con fuerte participación juvenil en la política.

La primera idea de provincia está vinculada a la presencia de una "sociedad fuertemente impregnada de creencias religiosas", ${ }^{76}$ con una ruralidad profunda representada en "las Altas Cumbres, el frío, las distancias, la adversidad". ${ }^{77}$ Estas ideas de provincia, según las cuales Córdoba es una provincia tradicional, se traducen en: 1) una noción sobre la comunidad política en la que "nadie de la oposición"78 tiene "la osadía de decir que quieren una educación laica; ${ }^{79}$ 2) una crisis de valores provocada por la modernidad, en "un mundo en el que todo fluye"; 80 3) y una mirada negativa sobre la diversidad religiosa, en la cual las minorías religiosas son percibidas como "sectas" coercitivas y peligrosas a las que hay que perseguir. Estos discursos hacen a una idea de provincia compatible con la memoria de la "Córdoba de las campanas", dogmática, inmutable y ordenada, sostenida por el NCC.

En este tipo de intervenciones en las que se presenta a Córdoba como "una sociedad fuertemente impregnada de creencias religiosas", ${ }^{81}$ se puede observar la apelación a una comunidad imaginada, dado que para el legislador que describe de ese modo a la sociedad es fácticamente imposible conocer a todos sus miembros y afirmar si la misma está impregnada de creencias religiosas o no. En la misma sintonía, en otra intervención ${ }^{82}$ se presenta a Córdoba como una provincia con ruralidad profunda, lo que se traduce en tres cuestiones. Por un lado, en la idea de una sociedad tradicional en la que la división del trabajo no está lo suficientemente desarrollada ${ }^{83}$ lo que deriva

\footnotetext{
${ }^{76}$ Dip. Genta, VT, 26.

${ }^{77}$ Dip. Rodríguez, VT, 64-65.

${ }^{78}$ Dip. Fernández, VT, 127-128.

${ }^{79}$ Dip. Fernández, VT, 126

${ }^{80}$ Dip. Fernández, VT, 125.

${ }^{81}$ Dip. Genta, VT, 26.

${ }^{82}$ Dip. Rodríguez, VT, 64-65.

${ }^{83}$ Émile Durkheim, La división del trabajo social (Buenos Aires: ediciones LEA, 2014).
} 
en que "[...] los docentes rurales muchas veces deben dar clases a niños de distintas edades y, a veces, con capacidades diferentes; deben ser cocineros, auxiliares, enfermeros y tener el cariño para abrazarlos a la noche y darles mucho pero mucho amor". En segundo lugar, de esta idea se deriva una comunidad imaginada como "esforzada y sacrificada" debido a que los pobladores viven en lugares alejados y bajo condiciones climáticas inclementes. En tercer lugar, de la apelación a la ruralidad se desprende la idea del abandono estatal. Según esta idea, la "comunidad educativa" que habita en las zonas rurales "cada año pelea por la vida sin tener conocimiento cierto de hasta dónde llega el horizonte" y por lo tanto está "librada a la deriva y a la buena de Dios". Todas estas definiciones refieren, en suma, a ideas de provincia previas a la consolidación del Estado nacional.

A partir de estas ideas de provincia relacionadas a lo tradicional, lo inmutable, lo dogmático y por lo tanto verdaderamente argentino, ${ }^{84}$ reaparece el planteo sostenido por el NCC de que la laicidad educativa es "una osadía". ${ }^{85}$ Además, la pretensión de una educación laica es presentada por este discurso como una amenaza a "los sistemas religiosos y filosóficos" por parte de "esta modernidad líquida" en la que "nadie cree en nada". ${ }^{86}$ La noción de que la modernidad constituye una amenaza a los valores, el orden y los sistemas de creencias que hacen a la forma de vida de los argentinos es un discurso recurrente en el catolicismo integral, no solo cordobés ${ }^{87}$ y en la nueva cristiandad. ${ }^{88}$ En la historia de Córdoba, estas acusaciones a los liberales, reformistas y radicales se hicieron en el marco de enfrentamientos particularmente intensos, sobre todo en dos momentos: la resistencia de las provincias a la Constitución unitaria de 1826, la cual preveía la libertad religiosa; ${ }^{89}$ y en las últimas décadas del siglo XIX y las primeras del siglo xx, durante el gobierno de Antonio del Viso (1877-1880). ${ }^{90}$

La representación de Córdoba como tradicional e impregnada de creencias religiosas (católicas), se traduce en un discurso sobre las minorías religiosas que tiende a criminalizar las prácticas, creencias y organizaciones que no forman parte de la Iglesia católica. De este modo, a la luz de una discusión que pone al catolicismo como eje en función del cual se dividen dos grupos de memoria y dos ideas de provincia que difieren entre sí, puede comprenderse que la cuestión de la legislación anti-sectas cordobesa apareciera en el debate de un proyecto que supuestamente no está vinculado a este tema, como es el de la ley provincial de educación. ${ }^{11}$

\footnotetext{
${ }^{84}$ Roitenburd, Educación y control social 59-119.

${ }^{85}$ Dip. Fernández, VT,127-128.

${ }^{86}$ Dip. Fernández, VT,127-128.

${ }^{87}$ Mallimaci, El mito 16.

${ }^{88}$ Esquivel, Detrás de los muros 27.

${ }^{89}$ Di Stéfano y Zanatta 214-235.

${ }^{90}$ Sobre este gobierno, Cárcano (1944: 53) escribió lo siguiente: “Al gobierno del doctor del Viso [...] se le ataca por liberal, quiere decir, irreligioso y profano. Sostenía la escuela normal, la enseñanza laica, el registro civil, la secularización de los cementerios, la redención de capellanías, la supresión de comunidades indígenas, el vicepatronato real, el ajuste de la Constitución. No existen otras imputaciones. El clero se considera lesionado en sus derechos y emprende la campaña contra el gobierno". Citado en Terzaga, Clericalismo 78.

${ }^{91}$ Dip. Fernández, VT, 132.
} 
La otra idea de provincia presente en el debate es la de una sociedad secular, que pretende tener educación laica, y que participa activamente en la vida pública de la provincia, particularmente la juventud. Desde esta idea de provincia, Córdoba constituye un caso que "no es el de otras provincias como Catamarca, Tucumán o Salta, que tienen educación religiosa obligatoria", ${ }^{92}$ sino que "un sector mayoritario de la sociedad pidió educación laica y no fue escuchado". ${ }^{93}$ Debido a que Córdoba es identificada como "la Docta" 94 por la presencia de una universidad a la que asisten muchos jóvenes formados y que fue el lugar en el que se desarrolló la Reforma Universitaria de 1918, aparece como una provincia en la cual la "participación" es una marca característica.

En este marco, se observa que esta idea de Córdoba secularizada, moderna y democrática se produce por oposición a otras provincias a las que se considera implícitamente tradicionales porque tienen educación religiosa obligatoria "en el $2010 ",{ }^{95}$ dando lugar a la idea de que la enseñanza de la religión en las escuelas estatales es algo del pasado. También con este objetivo se describe la intervención ("anuencia") del obispo como un signo de atraso. Este discurso da cuenta, además, de la idea de provincia como una comunidad imaginada como inherentemente limitada, dado que se construye una idea de provincia por oposición a otras provincias argentinas, de las cuales una (Catamarca) limita con Córdoba.

Otro fragmento del debate enfatiza, como rasgo cordobés, el hecho de que "[...] un sector mayoritario de nuestra sociedad -representado por quienes participaron de las Audiencias Públicas desarrolladas en torno a este proyecto- pidió por la educación laica y no fue escuchado". ${ }^{96}$ Este fragmento, coincidente con la idea de provincia moderna y secular, refiere, por un lado, al carácter imaginado de la comunidad. Esto se debe a que, el discurso del legislador cordobés para fundamentar su posición respecto a la laicidad educativa es que quienes concurrieron a las audiencias públicas en la Legislatura representan a "un sector mayoritario de la sociedad". Por otro lado, en este mismo discurso puede observarse el carácter de inherentemente soberana de la idea de provincia que marca Anderson en su definición de nación. Esto se debe a que se considera que la soberanía popular, expresada en este caso en las intervenciones en las audiencias públicas, debería determinar el sentido de la ley de educación.

Dentro de la idea de Córdoba como una provincia secular, moderna y rupturista, tiene mucha importancia la figura de "la participación", sobre todo de "los jóvenes", también llamados "estudiantes". Tal como se marcó en la introducción del caso, la noción de "participación" como un clivaje a la hora de establecer qué se entiende por democracia es central en Córdoba desde el período de conformación del Estado nacional. Hacia fines del siglo XIX, el nacionalismo católico mantenía una definición

\footnotetext{
${ }^{92}$ Dip. Genta, VT, 23.

${ }^{93}$ Dip. Ruiz, VT, 83.

${ }^{94}$ Dip. Ochoa, VT, 172.

${ }^{95}$ Dip. Genta, VT, 23.

${ }^{96}$ Dip. Ruiz, VT, 83.
} 
restrictiva de la democracia que la igualaba a la disolución y la anarquía; luego, la Reforma Universitaria, a partir de la demanda de mayor participación del claustro estudiantil en el gobierno de la universidad, abrió la puerta a un planteo, sintetizado por Taborda, de comprender a la participación como una parte de la formación básica y de la cultura política; el sabattinismo reactualizó esta idea de valorizar la democracia como participación en un contexto nacional de generalización del fraude electoral; el angelozismo, tomando el discurso alfonsinista y adaptándolo a la realidad cordobesa, retomó la cuestión de la participación política en la reforma educativa cordobesa, que luego se sintetizó en la Ley 8113. En suma, la cuestión de la participación como un rasgo cordobés está muy presente en el discurso de la tradición liberal-reformistaradical cordobesa, e incluso en el discurso de grupos e intelectuales de izquierda, que vieron en el Cordobazo una emergencia de este rasgo. ${ }^{97}$ Por este motivo, la cuestión de la participación estuvo presente en discursos legislativos referidos a esta idea moderna y secular de provincia. ${ }^{98}$

En suma, en el debate de la ley de Educación de Córdoba no existe una idea única de provincia sino dos: una vinculada al relato del NCC, y otra vinculada a la tradición liberal, luego reformista, y luego radical. De acuerdo con la primera idea de provincia, Córdoba es tradicional, tiene zonas de ruralidad profunda, está poco secularizada y es refractaria a las expresiones minoritarias de la diversidad religiosa. De a acuerdo a la segunda idea, Córdoba es moderna, la universidad tiene un rol central (es lo que la hace "la Docta") y la participación política de la comunidad es un componente inherente a su identidad.

Ambas ideas de provincia cuadran con la definición de nación de Anderson dado que son discursos que piensan a Córdoba como una comunidad, en un caso "fuertemente impregnada de creencias religiosas", en el otro que "quiere educación laica"; en ambos casos esta comunidad es imaginada a través de la figura de la generalización o bien a través de la figura de la representación; esta comunidad se imagina, en las dos ideas que aparecen en los distintos discursos políticos, como inherentemente limitada respecto de las demás provincias y con rasgos distintivos (como la tradición en un caso y la participación en el otro); y en ambos casos se imaginan como inherentemente soberanas dado que se invoca a la soberanía popular para sostener la preeminencia de tal o cual rasgo.

\subsection{Encuadramiento de la relación entre religión y educación en Córdoba: división y negociación}

A partir del análisis de la versión taquigráfica se pudieron identificar cuatro encuadramientos de la relación entre religión y educación en las escuelas estatales. Estos marcos fueron los siguientes: 1) la inclusión de la educación religiosa optativa como un tema que divide o "crispa" a la sociedad cordobesa; 99 2) la inclusión de la

\footnotetext{
${ }^{97}$ Aricó 10-14.

${ }^{98}$ Dip. Ochoa, VT, 172; Dip. Campana, VT,176; Dip. Olivero, VT, 114-115; Dip. Fernández, VT, 134.

${ }^{99}$ Dip. Coria, VT, 149.
} 
educación religiosa optativa como producto de una negociación o equilibrio; 3) la inclusión de la educación religiosa de manera optativa como una política que vulnera la laicidad educativa; 4) la inclusión de la educación religiosa como un "producto de la piedad popular".

La idea de que la inclusión de la enseñanza religiosa es algo que divide a la sociedad y a la comunidad política está asociada a la memoria colectiva que aparece en el debate en forma de memoria de la división. En otras palabras, el encuadramiento que entiende que la inclusión o no de la enseñanza religiosa en las escuelas de gestión estatal es una discusión que atraviesa a la sociedad cordobesa y la organiza en dos polos se desprende de la existencia de memorias e ideas de provincia que son antagónicas entre sí. Hasta aquí, este frame no es demasiado novedoso en relación con los discursos estudiados en los subapartados anteriores: si la laicidad del Estado es una disputa histórica en Córdoba (en función de la cual se organizan memorias e ideas de provincia) es esperable que la mirada sobre este antagonismo se traduzca en un encuadramiento de la relación entre educación y religión que ve en el tema un punto de conflicto y división. Pero hay una cuestión que resulta interesante para remarcar, y es que algunos legisladores citaron a Rafael Velasco, rector de la Universidad Católica de Córdoba y sacerdote, para referirse al encuadramiento de la relación entre educación y religión. Velasco, en un programa de televisión local, dijo que, si la enseñanza religiosa generaba “crispación”, el artículo de la ley que preveía la inclusión de la enseñanza religiosa de manera optativa debía ser eliminado. ${ }^{100}$ Esta apelación a una autoridad religiosa implicó un mecanismo similar al de la secularización estratégica, ${ }^{101}$ solo que invertido, en lo que se podría denominar una confesionalización estratégica: agentes seculares con intenciones laicistas toman argumentos vertidos por una autoridad religiosa para legitimar sus propósitos. ${ }^{102}$

El segundo encuadramiento de la relación entre educación y religión que estuvo presente en el debate fue la inclusión de la enseñanza religiosa de manera extracurricular como el resultado de una negociación entre dos posiciones antagónicas. Este encuadramiento reconoce en algunos casos implícitamente y en otros explícitamente la existencia de un conflicto entre dos posiciones antagónicas ante las cuales la comunidad política encontró una solución intermedia o negociada. Tal argumento puede observarse con mucha claridad en una intervención en la cual el legislador llama a esta posición "un justo equilibrio", ${ }^{103}$ no solo entre esas dos posiciones sino también entre "las legislaciones argentina y cordobesa". Esto último no puede comprenderse sin tener en cuenta la memoria de antagonismo entre Buenos Aires y Córdoba a fines del siglo XIX y sobre todo en la sanción de la Ley 1420. El texto de la Ley 26.206 (Ley de Educación Nacional) no se contradice, a priori, con la legislación cordobesa dado

\footnotetext{
100 "Velasco: Si la religión crispa, hay que sacar ese artículo", La Voz del Interior, (Córdoba) 19 de noviembre de 2010.

${ }^{101}$ Juan Marco Vaggione, "Reactive Politicization and Religious Dissidence. The Political Mutations of the Religious in Social Theory and Practice", Social Theory and Practice 31.2 (2005): 233-255.

${ }^{102}$ Dip. Genesio de Stabio, VT, 101; Dip. Ruiz, VT, 90.

${ }^{103}$ Dip. Genta, VT, 23.
} 
que no contiene definiciones sobre el sentido laico o confesional de la educación. Sin embargo, la memoria colectiva sobre la disputa por la aplicación de la Ley 1420 en Córdoba a fines del siglo XIX condiciona el encuadramiento del legislador, que comprende que dichas legislaciones son contradictorias entre sí y por lo tanto es necesario encontrar "un justo equilibrio".

En el mismo sentido, una intervención explicita el carácter "polémico"104 de la discusión sobre la inclusión o no de la enseñanza religiosa para marcar luego que el artículo del proyecto referido a la inclusión de la enseñanza religiosa en forma optativa y extracurricular es producto de una negociación. Para enfatizar la idea de negociación, el propio legislador afirma que él mismo hubiese querido eliminar el inciso de la educación religiosa pero que, dado que su posición era minoritaria, debió "ceder". De este modo, se pretende mostrar la explicitación del carácter extracurricular de la educación religiosa como un triunfo o avance de quienes querían remover el inciso. De manera similar, en otros fragmentos en los que también aparece el encuadramiento de la legislación como resultado de una negociación, el recurso principal que se utiliza para marcar dicha negociación como un avance de las posiciones laicistas es referirse al antagonismo inicial respecto a este tema como algo "complejo"105 o "amenazante". ${ }^{106}$

Los dos encuadramientos restantes se vinculan, por un lado, a la idea de que la educación debe ser "laica"; por otro lado, la idea de que la enseñanza religiosa debe estar presente porque es un reflejo de una sociedad religiosa o creyente. De acuerdo con el discurso sostenido por el primero de estos dos últimos encuadramientos, que considera que la educación debe ser "laica" o "aconfesional", la enseñanza religiosa no debe tener ningún tipo de injerencia en la educación estatal, ni siquiera de manera extracurricular. Por eso aparecen expresiones según las cuales "la escuela no puede ser un lugar que se confunda con la religión", 107 "la educación pública tiene que ser aconfesional", ${ }^{108}$ y "el culto no puede estar involucrado, de ninguna manera, con los colegios públicos". ${ }^{109}$ Este marco concibe a la religión como un asunto netamente privado y a las escuelas como un ámbito netamente público y a partir de esta distinción se considera que "tiene que haber un ámbito privado, que es el de la familia y el de los templos, donde se incluya cada uno de los cultos que se sostengan". ${ }^{110}$ Desde el punto de vista de este encuadramiento, la redacción del proyecto no constituye un equilibrio, como sostienen otros legisladores, sino un triunfo de una posición confesional.

Por último, en el encuadramiento que sostiene la necesidad de incluir a la enseñanza religiosa en las escuelas estatales, la misma es entendida como un reflejo de una sociedad que es "piadosa", como sinónimo de religiosa o creyente. De acuerdo

\footnotetext{
${ }^{104}$ Dip. Rivero, VT, 69.

${ }^{105}$ Dip. Genesio de Stabio, VT, 101.

${ }^{106}$ Dip. Rivero, VT, 70.

${ }^{107}$ Dip. Ruiz, VT, 91.

${ }^{108}$ Dip. Campana, VT, 181.

${ }^{109}$ Dip. Rossi, VT, 61.

${ }^{110}$ Dip. Rossi, VT, 61.
} 
con este encuadramiento, desde la propia sociedad civil, en la cual el catolicismo está fuertemente arraigado, existen acomodos o acuerdos entre las organizaciones religiosas y las escuelas y por lo tanto la legislación da cuenta de estos rasgos que ya están presentes en la propia sociedad. ${ }^{111}$

\section{Reflexión final}

El análisis de las intervenciones de los legisladores cordobeses arrojó cuatro hallazgos principales. En primer lugar, se observó que las referencias a los orígenes y al pasado de Córdoba se dividen en dos grupos. Uno que plantea que la historia cordobesa es una disputa o división entre el NCC, identificado por los legisladores como un sector “conservador" o "clerical”, y el liberalismo. Otro, más identificado con la tradición liberal-reformista cordobesa, considera que la Reforma Universitaria de 1918 constituye un hito importante del pasado de Córdoba. Este grupo ubica la Ley 1420, además, como un momento relevante para la historia cordobesa aunque esta ley no se aplicó en la provincia, lo cual marca especialmente la identificación con un grupo concreto que recuerda. En esta tradición, otros hitos de memoria que se remarcan son el gobierno de Sabattini y la Ley 8113, sancionada durante el gobierno de Angeloz. Esta idea del pasado pensado como disputa marca un destino de la provincia en el cual la religión cumple un rol divisivo: genera "crispación".

En segundo lugar, se halló que las ideas de provincia que aparecen en los discursos de los legisladores cordobeses difieren, y a partir de esta diferencia se pueden identificar dos grupos. Por un lado, surge de los discursos una idea de provincia impregnada de creencias religiosas, tradicional, con ruralidad profunda y para la cual la diversidad religiosa es un problema, que se resuelve a través de una legislación específica antisectas. Por otro lado, emerge de los discursos una idea de provincia secularizada y "docta", donde un sector mayoritario de la población quiere educación laica y en la cual la participación de la juventud en la política es un rasgo central.

En tercer lugar, se encontró que los marcos o frames de la relación entre religión y educación en las escuelas estatales que circularon en el debate parlamentario de la última ley de educación de Córdoba se corresponden con estas distintas ideas de provincia y memorias colectivas. De modo que la memoria colectiva de Córdoba como una memoria de la división o disputa entre dos grupos se corresponde con el encuadramiento que entiende a la inclusión de la educación religiosa optativa como un tema que "crispa" a la sociedad; esta misma memoria colectiva como memoria de la división se corresponde, además, con el encuadramiento que entiende a la inclusión de la educación religiosa optativa como producto de una negociación o "equilibrio". Por otro lado, la idea de Córdoba como una provincia secularizada, moderna y docta, se corresponde con un frame que considera a la inclusión de la educación religiosa de manera optativa como una política que vulnera la laicidad educativa. Por último, la idea de Córdoba como una provincia impregnada de creencias religiosas y tradicional

${ }^{111}$ Dip. Fernández, VT, 130. 
se relaciona con el marco según el cual la inclusión de la educación religiosa es un "producto de la piedad popular".

A partir de esto último, surge del análisis de los discursos que las memorias colectivas, las ideas de provincia y los marcos de la política educativa para cada grupo que recuerda están, en el caso del debate parlamentario de la última ley de educación en Córdoba, fuertemente relacionados entre sí, de modo que los fundamentos de la inclusión de la enseñanza religiosa de manera optativa, extracurricular y no financiada por el Estado no pueden escindirse de las diversas ideas de provincia, las cuales a la vez solo son comprensibles partiendo de los diversos relatos sobre el pasado de Córdoba.

\section{Bibliografía}

\section{Fuentes primarias}

\section{Fuentes de archivo}

Legislatura de la provincia De Córdoba (LPC). Cuerpo De Taquígrafos. $49^{\circ}$ Reunión. $45^{\circ}$ Sesión Ordinaria. 15 de diciembre de 2010. Versión Taquigráfica.

\section{Prensa}

La Voz del Interior (Córdoba) 2010.

\section{Entrevistas}

Sánchez, Carlos Alberto, entrevista realizada por María Sol Prieto. Córdoba, Argentina, mayo de 2016.

\section{Fuentes secundarias}

\section{Libros}

Anderson, Benedict. Comunidades imaginadas. Reflexiones sobre el origen y la difusión del nacionalismo. México, DF: FCE, 1993.

Botana, Natalio. El orden conservador. La política argentina entre 1880 y 1916. Buenos Aires: Sudamericana, 2010.

Di Stéfano, Roberto y Zanatta, Loris. Historia de la Iglesia argentina. Desde la conquista hasta fines del Siglo XX. Buenos Aires: Sudamericana, 2009.

Di Stefano, Roberto. Ovejas negras. Historia de los anticlericales argentinos. Buenos Aires: Sudamericana, 2010.

Durkheim, Émile. La división del trabajo social. Buenos Aires: ediciones LEA, 2014. 
Memorias colectivas, ideas de provincia y catolicismo en el debate parlamentario...

Esquivel, Juan. Detrás de los muros. La Iglesia católica e tiempos de Alfonsín y Menem (19831999). Quilmes: UNQ Editorial, 2004.

Halbwachs, Maurice. La memoria colectiva. Zaragoza: Prensas universitarias de Zaragoza, 2004.

Hervieu - Léger, Danièle. El Peregrino y el convertido. La religión en movimiento. México D. F: Ediciones del Helénico, 2004.

Hervieu-Léger, Danièle. La religion, hilo de memoria. Barcelona: Herder, 2005.

Ingenieros, José. Las direcciones filosóficas de la cultura argentina. Buenos Aires: El Aleph, 2000.

Ghio, José. La Iglesia Católica en la política argentina. Buenos Aires: Prometeo, 2007.

Mallimaci, Fortunato. El mito de la Argentina laica. Catolicismo, política y Estado. Buenos Aires: Capital Intelectual, 2015.

Orgaz, Arturo. Sarmiento y el naturalismo histórico. Córdoba: Imprenta Rossi, 1940.

Puiggrós, Adriana. Sujetos, disciplina y curriculum: en los orígenes del sistema educativo argentino, Vol. 1. Buenos Aires: Galerna, 1990.

Roitenburd, Silvia. Nacionalismo católico Córdoba (1862-1943): educación en los dogmas para un proyecto global restrictivo. Córdoba: Ferreyra Editor, 2000.

Sarmiento, Domingo. Facundo. Villa María: Eduvim, 2009.

Sigal, Silvia. Intelectuales y poder en Argentina: la década del sesenta. Buenos Aires: Siglo XXI, 2002.

Taborda, Saúl. Investigaciones Pedagógicas, Volumen I y II. Córdoba: Ediciones Ateneo Filosófico de Córdoba, 1951.

Tcatch, César. Sabattinismo y peronismo: partidos politicos en Córdoba, 1943-1955. Buenos Aires: Biblos, 2006.

Ternavasio, Marcela. Historia de la Argentina. 1806-1852. Buenos Aires: Siglo XXI, 2009.

Ternavasio, Marcela. La revolución del voto. Política y elecciones en Buenos Aires, 1810-1852. Buenos Aires: Siglo XXI, 2002.

Vasilachis de Gialdino, Irene. Estrategias de investigación cualitativa. Barcelona: Gedisa, 2006. 


\section{Capítulo de libros}

Cox, Gary. "The organization of Democratic Legislatures". The Oxford Handbook of Political Economy. Eds. Barry Weingast y Donald Wittman. Oxford: Oxford University Press, 2006.

Lamelas, Gabriela. "La invención de una tradición educativa. Disputas en torno al proceso de regulación normativa de la enseñanza de la religión en las escuelas públicas de Córdoba (1896-1923)". Historia, política y reforma educativa: Aportes críticos, transformaciones culturales y perspectiva en el espacio educativo argentino. Dirs. Silvia Roitenburd y Juan Pablo Abratte. Córdoba: UNC, 2016.

Mallimaci, Fortunato. "El Catolicismo. Entre el liberalismo integral y la hegemonía militar (1900-1960)". 500 años de cristianismo en Argentina. María Liboreiro y otros. Buenos Aires: Centro Nueva Tierra,1992.

Rein, Martin y Schön, Donald. "Reframing policy discourse". The argumentative turn in policy analysis and planning. Eds. Frank Fischer y John Forester. Durham, NC: Duke University Press, 1993.

Roitemburd, Silvia. "Educación y control social. El nacionalismo Católico Cordobés (18621944)". Historia de la educación en la Argentina IV. La educación en las provincias y los territorios nacionales (1885-1945). Dir. Adriana Puiggrós. Buenos Aires: Galerna, 1993.

\section{Artículos de revistas}

Aboy Carlés, Gerardo. "Populismo y democracia en la Argentina contemporánea. Entre el hegemonismo y la refundación”. Estudios Sociales 28 (2005): 125-149.

Abratte, Juan Pablo. "Las huellas de la ley 1.420 en la Provincia de Córdoba: Legislación educativa y enseñanza religiosa en perspectiva histórico-política". Historia de la educaciónanuario 16.1 (2015): 25-38.

Aricó, José. "Tradición y modernidad en la cultura cordobesa". Revista Plural 4.13 (1989): $10-14$.

Esquivel, Juan Cruz. "Cultura Política Y Poder Eclesiástico: Encrucijadas para la construcción del Estado laico en Argentina”. Archives De Sciences Sociales Des Religions 54.146 (2009): 41-59.

Gerring, John. "What Is a Case Study and What Is It Good for?". American Political Science Review 98.2 (2004): 341-354.

Navarro, Mina. "La antinomia tradición/modernidad en los intelectuales de la Reforma Universitaria de Córdoba en 1918. Un análisis desde la geopolítica histórica argentina". Andamios. Revista de Investigación Social 9.20 (2012): 35-61. 
Memorias colectivas, ideas de provincia y catolicismo en el debate parlamentario...

Tcatch, César. "Movimiento estudiantil e intelectualidad reformista en Argentina (1918-1946)". Cuadernos de historia, Santiago. 37 (2012): 131-157.

Terzaga, Alfredo. "Clericalismo y liberalismo: dos caras de la medalla cordobesa". Todo es Historia.75 (1973): 70-84.

Vaggione, Juan Marco. "Reactive Politicization and Religious Dissidence. The Political Mutations of the Religious in Social Theory and Practice". Social Theory and Practice 31.2 (2005): 233-255.

Tesis, ponencias, documentos y otros Inéditos

Abratte, Juan Pablo. "Hegemonía, reforma y discurso educativo en la provincia de Córdoba (1984-1999)". Tesis inédita de Doctorado en Ciencias Sociales, Flacso, Argentina, 2007.

Levita, Gabriel. "Élites políticas y nación: trayectorias sociales y representaciones sobre lo nacional de los senadores (2001-2011)". Tesis inédita de Doctorado en Ciencias Sociales (Universidad de Buenos Aires) y Sociología (Escuela de Estudios Superiores en Ciencias Sociales), 2014.

Perochena, Camila. "La historia en la disputa política: Los usos del pasado en el primer gobierno de Cristina, 2016. Fernández de Kirchner (2007-2011)”. Tesis inédita de Maestría en Ciencia Política, Universidad Torcuato Di Tella, 2016.

Roitenburd, Silvia. "Nacionalismo católico cordobés: educación en los dogmas para un proyecto global restrictivo, 1862-1943". Tesis inédita de Doctorado en Historia, Universidad Nacional de Córdoba, 1998. 